\title{
АВТОМАТИЗАЦІЯ ПРОЦЕСУ ДИСТИЛЯЦІї МІСЦЕЛИ
}

\author{
Дишлєвой О. О. ${ }^{1}$, Світий I. М. ${ }^{2}$, Воінова С. О. ${ }^{3}$ \\ 1,2,3 Одеська національна академія харчових технологій \\ ORCID: ${ }^{1}$ 0000-0001-7862-5930; ${ }^{2}$ 0000-0001-8524-5565; ${ }^{3} 0000-0003-0203-0599$ \\ E-mail: ${ }^{1}$ aleksandrdys99@gmail.com
}

Copyright (C) 2021 by author and the journal “Automation of technological and business - processes”.

This work is licensed under the Creative Commons Attribution International License (CC BY).

http://creativecommons.org/licanses/by/4.0

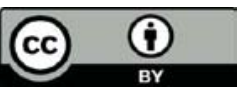

ONAFT

Open Access

DOI:

Анотація. Соняшникова олія для Украӥни - продукт стратегічний. Вона є важливим джерелом валютних надходжень до країни та иінним харчовим продуктом для ї̈ громадян. Зростаюча конкуренція на світових ринках, зокрема на ринку соняшникової олії, вимагає впровадження технологій, щзо забезпечують підвищення якості та зниження собівартості готової продукиії. А ие вимагає підвищення вимог до точності керування процесами.

У даній роботі для досягнення мети підвищення ефективності виробнищтва рафінованої сонямникової олії було означено задачу підвищення ефективності системи автоматичного регулювання (САР) параметрів процесу дистиляиї місцели.

Аналіз літературних джерел з розробки САР для процесу дистиляиії місиели виявив значний резерв підвищення ефективності керування процесом.

Для вирішення задачі побудови ефективної САР процес дистиляиіі місцели в трубчастому дистиляторі було проаналізовано як об’єкт керування (ОК), було отримано його концептуальну модель, проідентифіковано математичну модель, яку відтворено в середовищі імітаційного моделювання у вигляді імітаційної моделі.

На першому етапі синтезу САР реалізовано, як двоканальну САР температури та рівню місиели. Надалі здійснювалося підвищувалася динамічна точність САР иляхом забезпечення автономності контуру регулювання рівню. Наступним етапом було досліджено вплив варіації параметрів ОК на якість керування. Запропоновано алгоритми керування на основі нечіткого та нейронного регулятора. Подальші дослідження пов'язані з розширенням моделі ОК за рахунок введення моделі концентрації гексану, щзо $\epsilon$ безпосереднім показником якості олії. Запропоновано каскадний контур регулювання концентрації гексану з проміжною точкою: температурою дистиляиії місиели. Подальші дослідження пов'язані з доповненням каскадної САР контуром гарантування, щзо забезпечує підвищення ефективності САР в умовах дії інтенсивних координатних та параметричних збурень.

На всіх етапах синтезу варіанти САР було проаналізовано на відповідність гранично припустимим вимогам та на «грубість» або чутливість до варіації параметрів об’єкту керування.

В роботі також опрацьовано питання програмної реалізації розроблених алгоритмів регулювання в середовищі TIA Portal та програмної взаємодї з оператором установки иляхом розробки графічного інтерфейсу взаємодії на основі SCADA.

У майбутньому запропоновані рішення складуть основу модернізованої ефективної системи керування процесом дистиляції місиели, яка є інтелектуальним ядром автоматизованого робочого місия оператора.

Abstract. Sunflower oil is a strategic product for Ukraine. It is an important source of foreign exchange earnings to the country and a valuable food product for its citizens. Growing competition in world markets, in particular in the sunflower oil market, requires the introduction of technologies that improve the quality and reduce the cost of finished products. And this requires increasing the requirements for the accuracy of control process.

In this work, to achieve the goal of increasing the efficiency of production of refined sunflower oil, the problem of increasing the efficiency of the system of automatic control (ACS) of the parameters of the miscella distillation process was identified.

Analysis of the literature on the development of ACS for the miscella distillation process revealed a significant reserve for improving the efficiency of process control.

To solve the problem of designing an effective ACS, the miscella distillation process in a tubular distiller was analyzed as an object of control (CO), its conceptual model was obtained, a mathematical model was identified, which was reproduced in the simulation software as a simulation model.

At the first stage of ACS synthesis, it is realized as two-channel ACS of temperature and level of miscella. Further, the dynamic accuracy of the ACS was increased by ensuring the autonomy of the level control circuit. The next step was to investigate the effect of variation of CO parameters on control quality. Control algorithms based on fuzzy and neural regulators are proposed. Further research is related to the expansion of the CO model by introducing a model of hexane 
concentration, which is a direct indicator of oil quality. A cascade circuit for regulating the concentration of hexane with an intermediate point: the miscella distillation temperature is proposed. Further research is connected with the addition of cascade ACS to the guarantee circuit, which provides an increase in the efficiency of ACS in the conditions of intense coordinate and parametric perturbations.

At all stages of the synthesis, the ACS variants were analyzed for compliance with the maximum allowable requirements and for "roughness" or sensitivity to variation of the parameters of the control object.

The paper also deals with the issue of software implementation of the developed control algorithms in the TIA Portal and software interaction with the installation operator by developing a graphical interface for interaction based on SCADA.

In the future, the proposed solutions will form the basis of an upgraded efficient control system for the miscella distillation process, which is the intelligent core of the automated operator's workplace.

Ключові слова: дистиляція місцели, трубчастий дистилятор, система автоматичного регулювання, об єкт керування, ефективне керування.

Keywords: miscella distillation process, tubular distiller, automatic control system, control object, effective control.

Вступ. Україна - світовий лідер з виробництва та експорту соняшникової олії [1]. Країна задовольняє власні потреби вітчизняним продуктом. А соняшникова олія, як експортний продукт, займає чільні позиції у обсязі експорту продукції з нашої країни. Олія відіграє важливу роль в житті людини як харчова, кормова, косметична добавка, основне джерело рослинних жирів для організму людини, сировина для виробництва майонезу, маргарину, тощо.

Виробництво очищеної або рафінованої соняшникової олії здійснюється на олієекстракційних заводах. Основними статтями підвищення конкурентоспроможності таких підприємств є зниження енергоємності виробництва та підвищення якості готового продукту. Зростаюча конкуренція на світових ринках, зокрема на ринку соняшникової олії, вимагає впровадження технологій, що забезпечують підвищення якості та зниження собівартості готової продукції. Одним $з$ найефективніших і перевірених практикою способів досягнення означеної мети $є$ підвищення інтелектуального рівню алгоритмів керування ключовими технологічними процесами за рахунок підвищення вимог до точності керування процесами.

Процес виробництва рафінованої олії включає ряд важливих енергомістких процесів. Одним 3 таких процесів $є$ процес дистиляції місцели. Цей процес $є$ визначальним у формуванні якості готової продукції, тому підвищення вимог до якості регулювання режимних параметрів саме цього процесу є цілком природнім.

Аналіз літературних даних і постановка проблеми. Оскільки автоматизація технологічного процесу дистиляції місцели є актуальною задачею, багато дослідників займалися цим питанням. Так Я.М. Лесов запропонував спосіб автоматичного керування процесом дистиляції олійних місцел, в якому передбачено підтримку заданої концентрації місцели за вмістом олії шляхом зміни витрат гріючої пари [2]. Також відомий спосіб, який запропонував В.Т. Золочевский, даний спосіб передбачає автоматичне керування процесом дистиляції олійних місцел, який включає підтримку заданої температури місцели на рівні 95-100 ${ }^{\circ} \mathrm{C}$ шляхом зміни витрат гріючої пари [3]. Н.П. Рябченко запропонував спосіб автоматичного керування процесом дистиляції олійних місцел, в якому передбачено підтримку заданої температури місцели на рівні $90-95{ }^{\circ} \mathrm{C}$ шляхом зміни витрат гріючої пари [4]. Відомий спосіб, який запропонував Ю.В. Іванов, він передбачає автоматичне керування процесом дистиляції олійних місцел, який включає підтримку заданої концентрації місцели за олією шляхом зміни витрат гріючої пари [5]. Також фірма «НUM» запропонувала спосіб автоматичного керування процесом дистиляції олійних місцел, який містить регулювання температури місцели шляхом зміни витрат гріючої пари в нагрівальну секцію дистилятора [6].

Однак у всіх розглянутих вище рішеннях є загальний недолік - низька якість дистиляції місцели через недостатню стабільність процесу упарювання в результаті недостатньої стабільності подачі місцели на наступні контури дистиляції. Отже, існує певний запас підвищення ефективності керування процесом.

Мета і завдання досліджень. Виходячи 3 наведених вище чинників сформулюємо мету дослідження, як підвищення ефективності процесу виробництва рафінованої соняшникової олії за рахунок підвищення якості готової продукції. Аналіз технологічного процесу виробництва дозволив сформулювати окрему мету, як підвищення ефективності процесу дистиляції місцели, досягнення якої дозволить суттєво продвинутися в досягненні глобальної мети. Власне, мету підвищення ефективності процесу дистиляції місцели. Одним 3 дієвих і перевірених практикою способів досягнення мети є підвищення вимог до точності регулювання режимних параметрів процесу i, зокрема, якісних показників процесу. Тому досягнення означеної мети можна звести до розв'язання задачі підвищення якості регулювання режимних параметрів процесу дистиляції місцели. Для розв'язання цієї задачі слід провести ідентифікацію моделі процесу, провести синтез та аналіз варіантів САР, здійснити програмну реалізацію алгоритмів регулювання та інтегрування розроблених алгоритмів до автоматизованого робочого місця (АРМ) оператора процесу.

Методи і матеріали досліджень. Основним використаним методом дослідження є метод системного аналізу. Для ідентифікації моделей було використано методи активного та пасивного експерименту, метод типової статистичної ідентифікації та інженерні методики ідентифікації моделей ОК [7]. При синтезі САР було використано методи теорії автоматичного керування, а саме інженерні методики параметричного синтезу САР, оптимальний параметричний синтез [8], принципи інваріантності та автономності [9], методи нечітких множин та нейронних мереж, методи теорії гарантуючого керування [10]. Основним експериментальним методом обрано імітаційне моделювання.

Результати досліджень. Першим етапом вирішення задачі побудови ефективної САР процес дистиляції місцели в трубчастому дистиляторі було проаналізовано як ОК, проаналізовано матеріальний, тепловий та масообмінний 
баланси процесу, виявлено ключові параметри процесу. У результаті було параметризовано технологічну схему процесу (рис. 1). Проведено класифікацію регламентованих параметрів 3 подальним виділенням температури та рівню місцели в якості регульованих координат. Також було проаналізовано вплив параметрів зовнішнього середовища на хід процесу з подальшим виділенням керуючих дій та збурень. Результатом цієї роботи стала структурна схема процесу дистиляції місцели як ОК, яка по суті є концептуальною моделлю процесу. Надалі експериментальними методами було проідентифіковано математичні моделі динаміки та статики каналів перетворення керуючих дій, а методом пасивного експерименту та подальшої типової статистичної ідентифікації отримано математичну модель координатних неконтрольованих збурень. Математичні моделі було відтворено у середовищі імітаційного моделювання, перевірено на схожість з експериментальними даними та підготовлено до машинних експериментів для синтезу і аналізу варіантів САР.

Наступні етапи зводилися до синтезу та аналізу САР різних ступенів складності.

На другому етапі синтезу систему регулювання реалізовано, як двоканальну САР температури та рівню місцели. В якості базового було обрано ПІД-алгоритм регулювання. Параметричний синтез САР проводився спочатку за інженерними методиками, а потім оптимальним параметричним синтезом за інтегральним модульним критерієм.

Надалі здійснювалося підвищення динамічної точність САР шляхом забезпечення автономності контуру регулювання рівню (рис. 2). Для цього було розраховано передаточну функцію коригуючого регулятора, визначено початкові наближення його параметрів, проведено оптимальний параметричний синтез САР.

Наступним етапом було досліджено вплив варіації параметрів ОК на якість керування. 3 цією метою до моделі ОК в канал температури місцели було введено нелінійність, яка, певним чином, і покликана зімітувати таку невизначеність. Запропоновано алгоритми керування на основі нечіткого та нейронного регулятора.

Подальші дослідження пов’язані з розширенням моделі ОК за рахунок введення моделі концентрації гексану, що $є$ безпосереднім показником якості олії (рис. 3). Запропоновано каскадний контур регулювання концентрації гексану 3 проміжною точкою: температурою дистиляції місцели (рис. 4). Подальші розвитком системи регулювання стали дослідження, пов'язані 3 доповненням каскадної САР контуром гарантування, що забезпечує підвищення ефективності САР в умовах дії інтенсивних координатних та параметричних збурень (рис. 5).

У розвиток запропонованих рішень 3 підвищення ефективності регулювання параметрів процесу дистиляції місцели було опрацьовано питання програмної реалізації запропонованих алгоритмів на базі контролера SIMATIC S7300 фірми Siemens. У подальшому було створено SCADA процесу в середовищі TIA Portal (рис. 6). Метою цього була інтеграція запропонованих алгоритмів автоматичного регулювання до АРМ оператора-технолога і наладчика САК ділянки дистиляції місцели лінії виробництва рафінованої соняшникової олії.

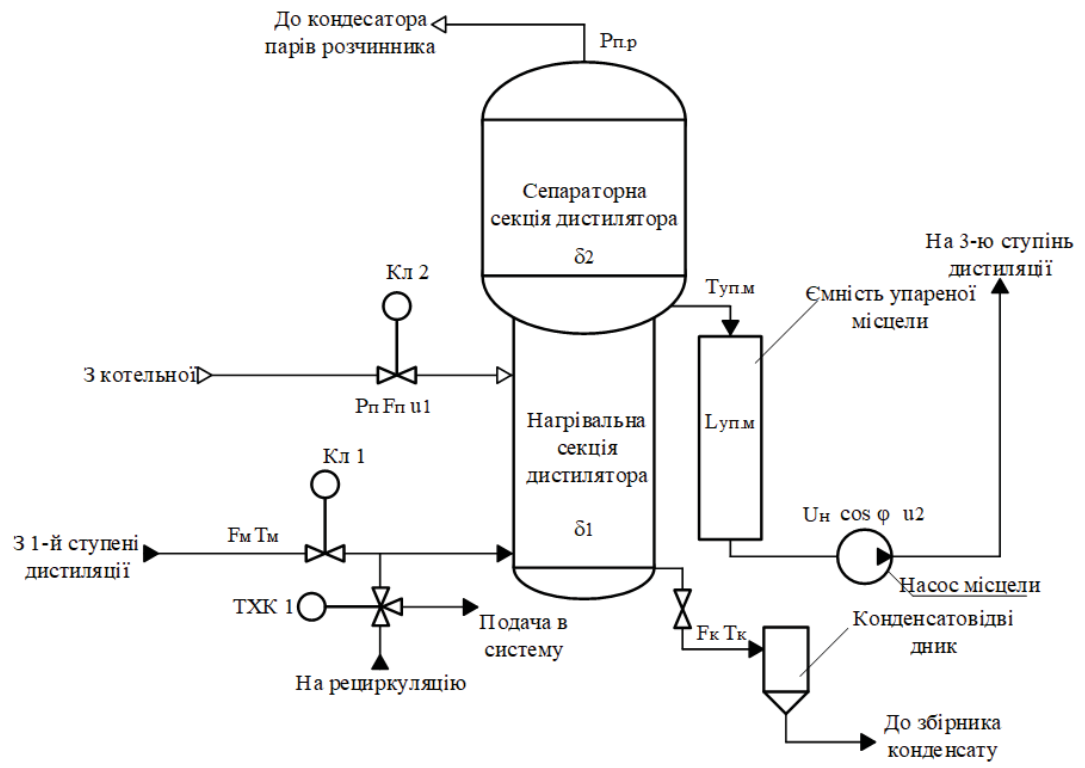

Рис. 1 - Параметризована технологічна схема процесу дистиляції міцели

Fм - витрати вхідної місцели, т/год;

Тм - температура вхідної місцели, ${ }^{\circ} \mathrm{C}$;

Рп - тиск пари, МПа;

Fп - витрати пари, кг/год;

u1 - положення РО для зміни витрати пари, \%;

Тк - температура конденсату, ${ }^{\circ} \mathrm{C}$;

Fк - витрати конденсату, кг/г;

Рп.р - розрідження в сепараторній секції дистилятора для відведення парів розчинника, МПа; $\delta 1$ - наліт на трубах нагрівальної секції, \%;

$\delta 2$ - наліт в сепараторної секції, \%;

Туп.м - температура упареної місцели на виході 3 дистилятора, ${ }^{\circ} \mathrm{C}$;

Цуп.м - рівень упареної місцели в ємності, \%;

u2 - положення регулюючого органу зміни частоти електроприводу насосу, \%;

$\mathrm{UH}$ - напруга в ланцюзі живлення електродвигуна насосу, B;

$\cos \varphi$ - коефіцієнт потужності. 


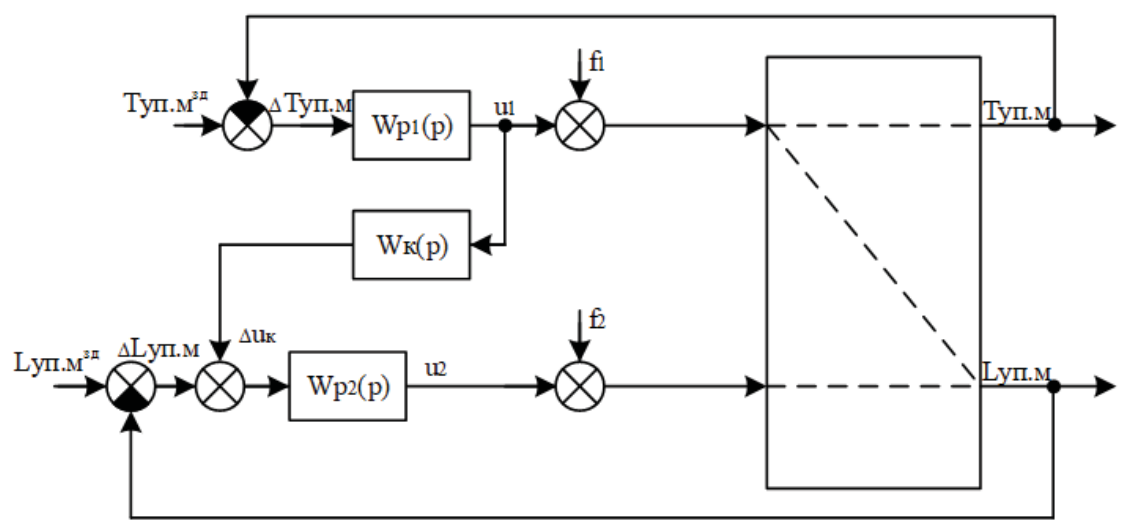

Рис. 2 - Структурна схема автономної системи керування

$\mathrm{W}_{\mathrm{P} 1}(\mathrm{p})$ - передаточна функція регулятора температури дистиляції місцели;

$\mathrm{W}_{\mathrm{P2}}(\mathrm{p})$ - передаточна функція регулятора рівня місцели в ємності;

$\mathrm{W}_{\mathrm{K}}(\mathrm{p})$ - передаточна функція коригуючою ланки; Туп.м $^{\text {зд }}$ - задане значення температури дистиляції місцели;
$\Delta$ Туп.м - помилка регулювання значення температури дистиляції місцели;

Lуп.м Зд - задане значення рівня місцели в емності;

$\Delta$ Lуп.м - помилка регулювання значення рівня місцели в ємності;

$\Delta$ ик - вплив коригуючого зв'язку;

f1, f2 - вектор неконтрольованих збурень.

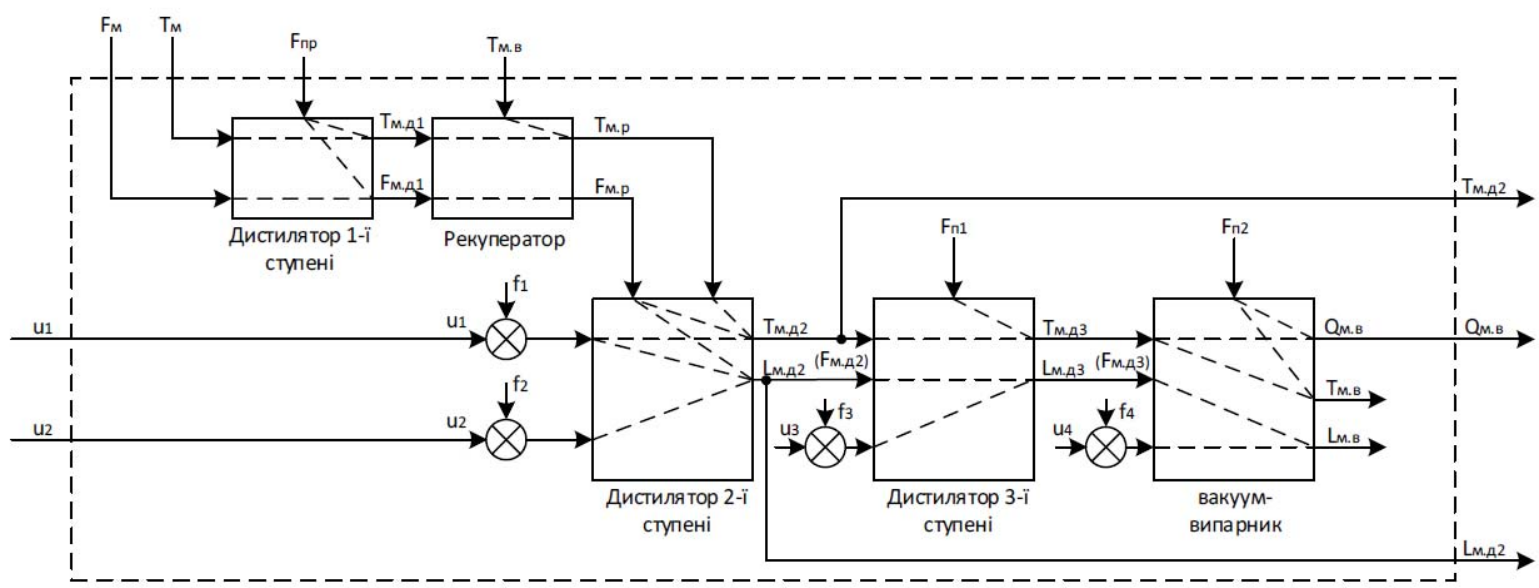

Рис. 3 - Структурна схема лінії дистиляції місцели як ОК

Тм - температура місцели на вході лінії дистиляції;

Fм - витрата місцели на вході лінії дистиляції;

Fпр - витрата відхідних несконденсованих парів розчинника;

Тм.сд1 - температура місцели на виході з 1й секції дистиляції;

Fм.сд1 - витрата місцели на виході 3 1й секції дистиляції;

Тм.в - температура місцели на виході 3 вакуумвипарника;

Тм.р - температура місцели на виході 3 рекуператора;

Fм.p - витрата місцели на виході з рекуператора; u1 - положення РО для зміни витрати пари; u2 - положення РО зміни частоти ЕД насоса №1;

Тм.сд2 - температура місцели на виході з 2й секції дистиляції;

Lм.сд2 (Fм.сд2) - рівень в ємності (витрата) місцели на виході з 2й секції дистиляції; u3 - положення РО зміни частоти ЕД насоса №2;

Тм.сд3 - температура місцели на виході з 3й секції дистиляції;

Lм.сд3 (Fм.сд3) - рівень в ємності (витрата) місцели на виході з Зй секції дистиляції;

Fп1 - витрата несконденсованого пара у 2й секції дистиляції;

u4 - положення РО зміни частоти ЕД насоса №3;

Qм.в - вміст гексана в місцели на виході з вакуумвипарника;

Тм.в - температура місцели на виході 3 вакуумвипарника;

Lм.в (Fм.сд3) - рівень в ємності (витрата) місцели на виході з вакуум-випарника;

Fп2 - витрата несконденсованого пара у 2й секції дистиляції;

f1, f2, f3, f4 - вектор неконтрольованих збурень. 


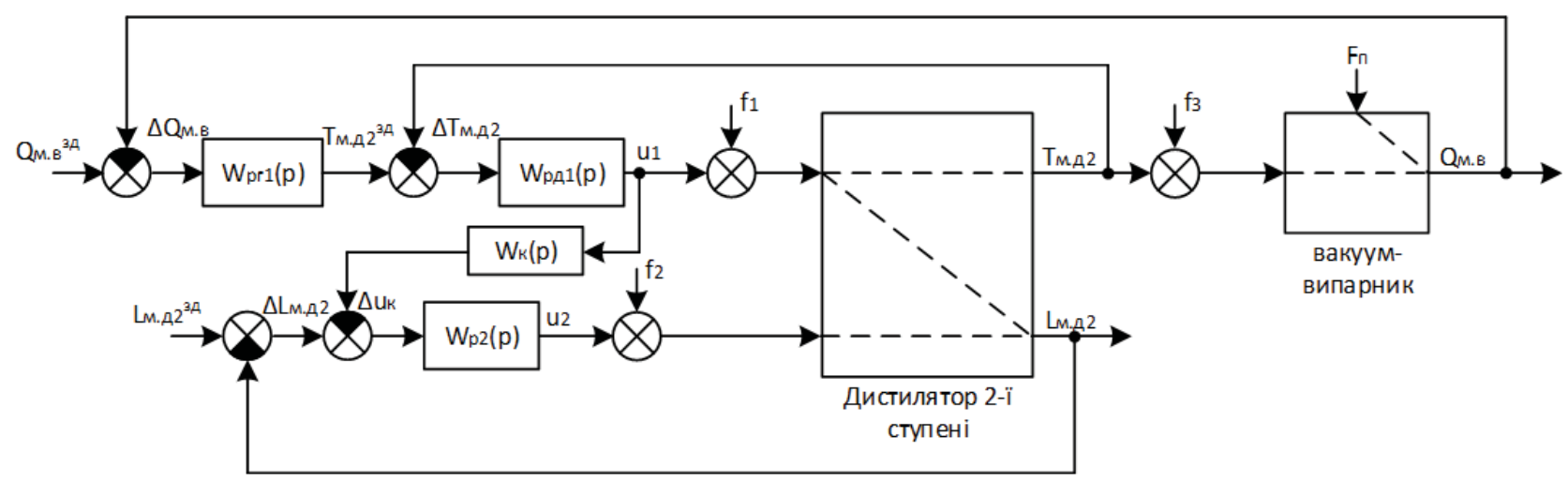

Рис. 4 - Структурна схема каскадної системи керування

$\mathrm{W}_{\text {РГ1 }}(\mathrm{p})$ - передаточна функція головного регулятора вмісту гексана в місцели на виході з вакуум-випарника;

$\mathrm{W}_{\text {Рд1 }}(\mathrm{p})$ - передаточна функція допоміжного регулятора температури дистиляції місцели;

Qм.в ${ }^{\text {3Д }}$ - задане значення вмісту гексана в місцели на виході з вакуум-випарника;

$\Delta Q$ м.в - помилка регулювання значення вмісту гексана в місцели на виході з вакуум-випарника.

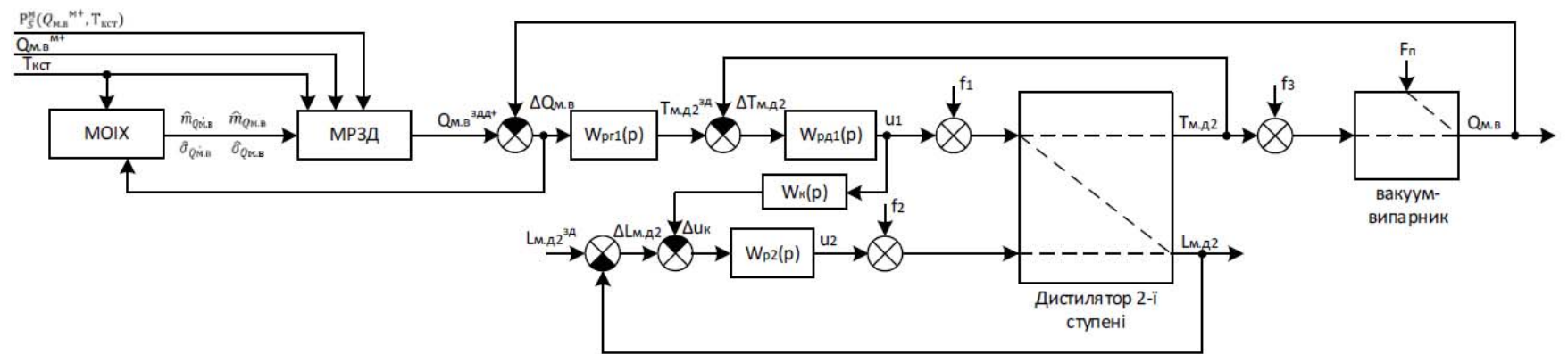

Рис. 5 - Структурна схема гарантуючої системи керування

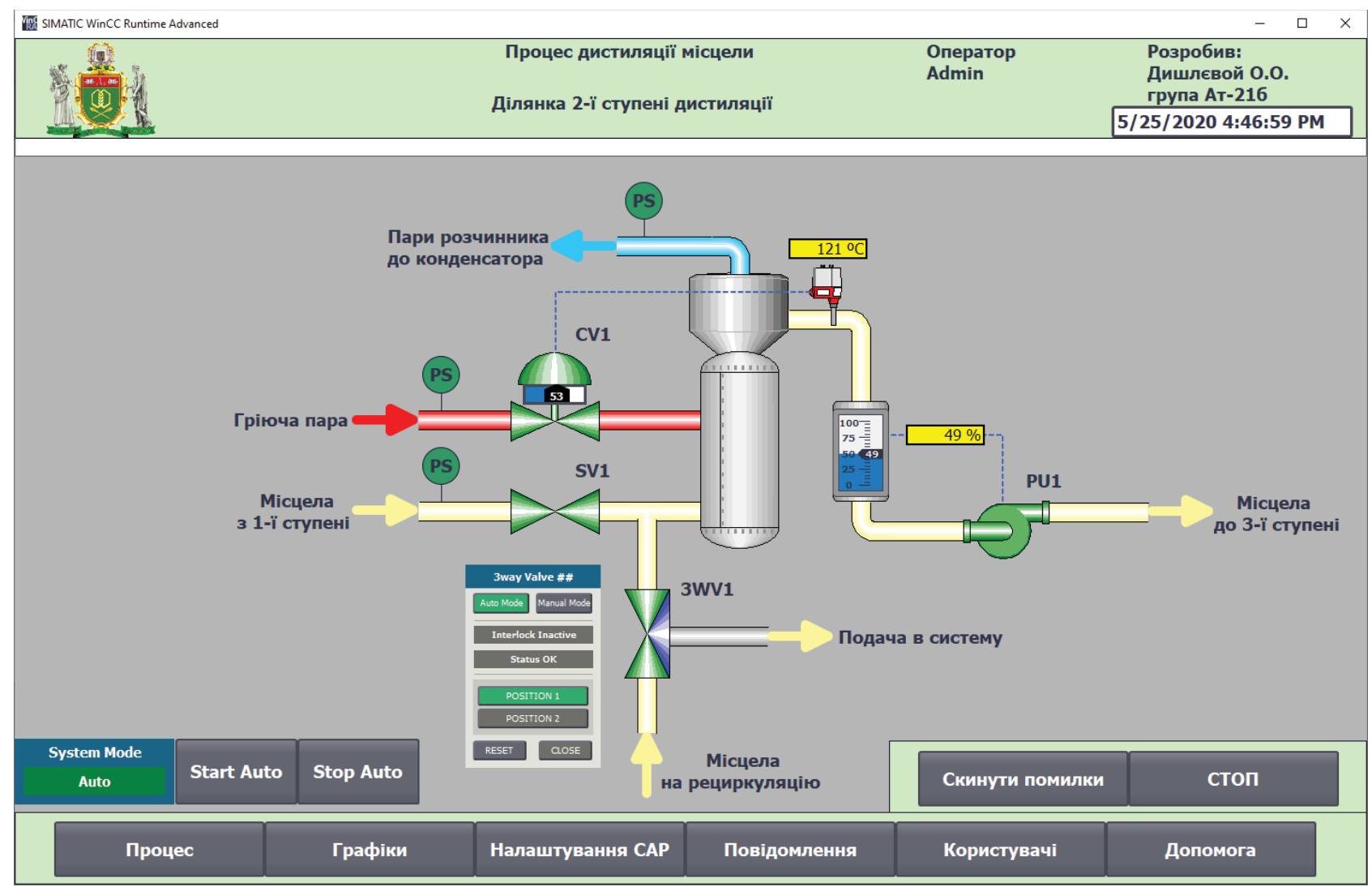

Рис. 6 - Загальний вид екрану «Рrocess» при нормальній роботі 
Обговорення результатів досліджень. У результаті ідентифікації математичних моделей процесу дистиляції місцели як ОК дозволив зробити висновки, що канали ОК можуть бути описаними статичними аперіодичними ланками першого або другого порядку та ланками запізнення.

Модель неконтрольованих збурень, що діють на температуру упарювання місцели можуть розглядатися, як випадкові процеси описані типовою моделлю №6.

Підготовка моделі ОК до машинних експериментів для синтезу і аналізу варіантів САР передбачає реалізацію математичних моделей ОК комплексно у абсолютних величинах. Це дозволило дослідити роботу варіантів САР в умовах вимушеного руху системи, виключаючи при цьому власний рух системи, який, в нашому випадку є вадами налаштування моделі ОК.

Аналіз якості роботи варіантів САР проводився на предмет дотримання гранично припустимих вимог. Наприклад, було встановлено, що САР базової і автономної структури відповідають гранично-припустимим вимогам (рис. 7). Також варіанти САР було проаналізовано на виконання умови «грубості» САР, тобто несуттєвої чутливості до 20\%-ї варіації параметрів ОК. При цьому було проаналізовано роботу варіантів САР у першу чергу на стійкість, а потім і на відповідність гранично припустимим вимогам.
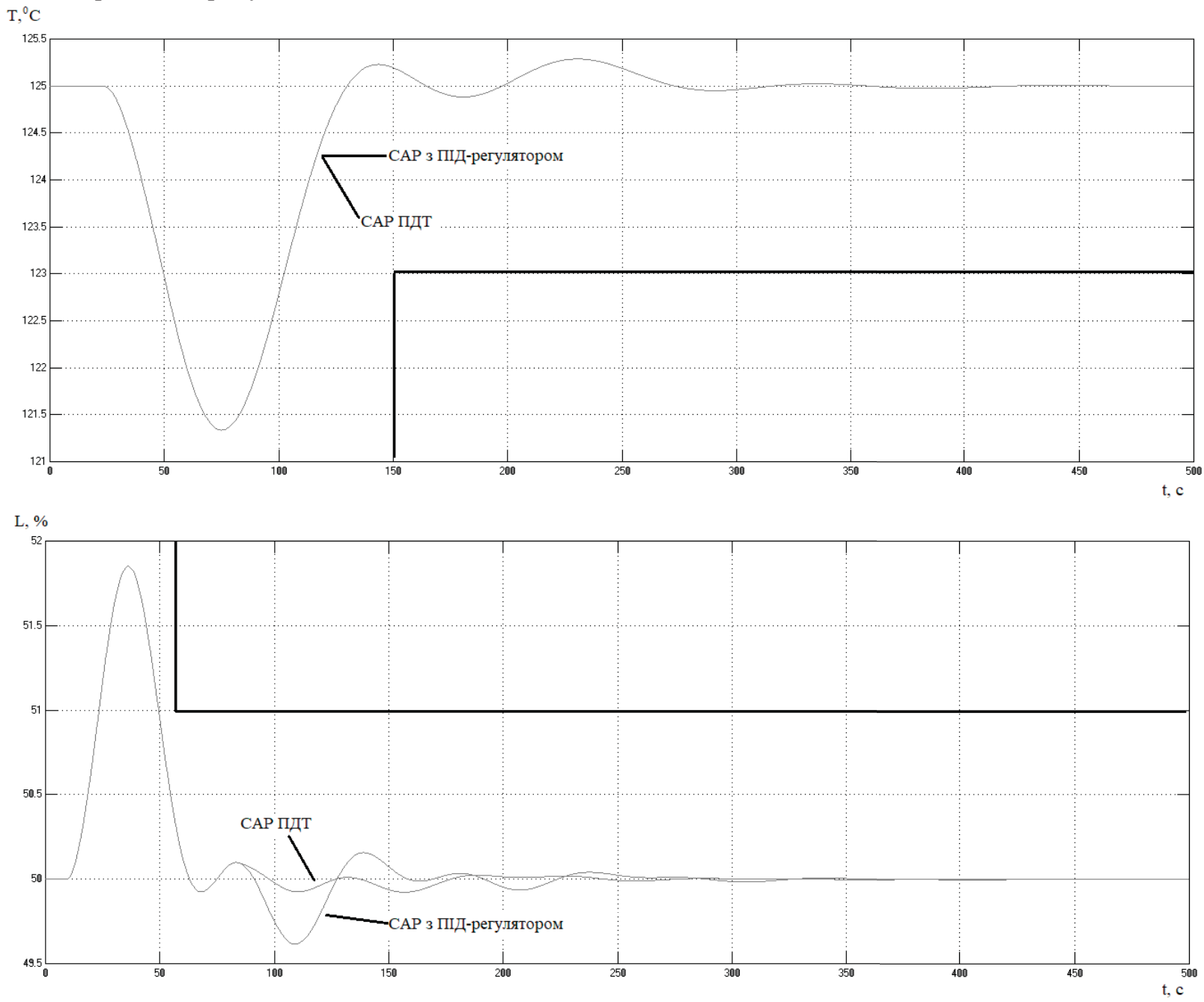

Рис. 7 - Результати порівняння САР базової структури та САР підвищеної динамічної точності

Порівняння варіантів САР базової структури і автономної структури проводилося за інтегральним показником та за прямими показниками (табл. 1) та дозволило зробити висновок про недоцільність технічної реалізації САР автономної структури через незначну її перевагу над базовою.

Таблиця 1 - Результати порівняння САР базової структури та САР підвищеної динамічної точності

\begin{tabular}{|c|c|c|c|c|c|}
\hline CAP & $\Delta \mathrm{Tmax},{ }^{\circ} \mathrm{C}$ & $\mathrm{T}_{\text {ппт }}, \mathrm{c}$ & $\Delta \mathrm{Lmax}, \%$ & $\mathrm{~T}_{\mathrm{m \Pi L}}, \mathrm{c}$ & $J$ \\
\hline ПІД & 3,7 & 102,2 & 1,8 & 49,3 & 182,2 \\
\hline ПДТ & 3,7 & 102,2 & 1,8 & 49,3 & 172,9 \\
\hline
\end{tabular}


Подальші удосконалення САР стосувалися підвищення якості регулювання температури в умовах дії інтенсивних параметричних та координатних збурень. САР температури було розширено до САР концентрації гексану, як безпосереднього якісного показника процесу дистиляції.

Розроблена в TIA Portal програмна реалізація алгоритмів регулювання включає алгоритми автоматичного пуску, автоматичної технологічної та аварійної зупинки, можливість ручного керування, а також автономність контурів регулювання, та може бути розширена до САР каскадної структури, нечіткої структури та доповнена функцією гарантування.

\section{Висновки}

1. Процес дистиляції місцели є складовою процесу виробництва рафінованої соняшникової олії, що визначає ступінь очищеності готової продукції, а точність реалізації процесу напряму впливає на якість очищення готового продукту від залишків розчинника. Тому задача підвищення вимог до якості регулювання режимних параметрів $\epsilon$ природньо актуальною для досягнення мети, тобто підвищення якості готового продукту.

2. Дистилятор як об'єкт керування являє собою складну динамічну систему. Аналіз існуючих систем автоматичного керування процесом дистиляції місцели демонструє наявність значного запасу підвищення ефективності процесу.

3. В ході роботи було запропоновано шість варіантів САР для процесу дистиляції місцели.

4. Результати структурно-параметричного синтезу і аналізу варіантів САР підтверджують переваги і недоліки запропонованих підходів.

5. Запропоновані варіанти програмного забезпечення дозволять суттєво підвищити ефективність сучасного робочого інструменту оператора процесу дистиляції місцели, а саме його АРМ. Також має підвищитися рівень технічної підтримки АРМ оператора за рахунок удосконалення АРМ наладчика автоматизованих систем контролю та вимірювання.

6. Подальший розвиток питання автоматизації керування процесом дистиляції місцели знайде в поглибленому дослідженні і подальшому вдосконаленні САР на базі апарату нечітких множин, нейронних мереж, гарантуючого керування.

\section{Список використаних джерел}

[1]. Офіційний сайт Українського клубу аграрного бізнесу. URL: http://ucab.ua/ua/pres_sluzhba/novosti/ infografika_zovnishnya_torgivlya_sonyashnikovoyu_olieyu

[2]. AC №1549990 A1 SU. Способ управления процессом предварительной многоступенчатой дистилляции масличных мисцелл / Я.М. Лесов и др. МПК С11В 1/10. Заявл. 21.08.87 №4299956/28-13. Опубл. 15.03.90. Бюл. №10. $-4 \mathrm{c}$.

[3]. AC №897840 SU. Способ предварительной дистилляции масляных мисцелл / В.Т. Золочевский и др. МПК С11В 1/10. Заявл. 19.03.80 №2899329/28-13. Опубл. 15.01.82. Бюл. №2. - 8c.

[4]. AC №806749 SU. Способ дистилляции масляных мисцелл / Н.П. Рябченко и др. МПК С11B 1/10. Заявл. 07.06.78 №2647758/28-13. Опубл. 23.02.81. Бюл. №7. - 6с.

[5]. AC №721473 SU. Способ дистилляции масляных мисцелл / Ю.В. Иванов и др. МПК С11В 1/10. Заявл. 16.08.77 №2519375/28-13. Опубл. 15.03.80. Бюл. №10. - 3c.

[6]. Офіційний сайт фірми «HUM». URL: http://hum.com.tr/teknolojiler-ru_3/kstraktsiya/

[7]. Хобін В.А. Конспект лекцій з курсу «Ідентифікація та моделювання технологічних об єктів» для студентів, які навчаються за спеціальністю 151«Автоматизація та комп`ютерно-інтегровані технології» денної та заочної форми навчання.- Одеса: ОНАХТ, 2016 - 96с.

[8]. Хобін В.А. Конспект лекцій 3 курсу «Теорія автоматичного керування» для студентів, які навчаються за спеціальністю 151«Автоматизація та комп ютерно-інтегровані технології» денної та заочної форми навчання.Одеса: ОНАХТ, 2012.-Ч.1-112c.

[9]. Хобін В.А. Конспект лекцій з курсу «Теорія автоматичного керування» для студентів, які навчаються за спеціальністю 151«Автоматизація та комп ютерно-інтегровані технології» денної та заочної форми навчання.Одеса: ОНАХТ, 2019.-Ч.2-72c.

[10]. Хобин В.А. Системы гарантирующего управления технологическими агрегатами: основы теории, практика применения. / Одесская национальная академия пищевых технологий - Одесса: «ТЭС», 2008. - 306 с.

\section{References}

[1]. Ofitsiinyi sait Ukrainskoho klubu ahrarnoho biznesu. URL: http://ucab.ua/ua/pres_sluzhba/novosti/ infografika_zovnishnya_torgivlya_sonyashnikovoyu_olieyu

[2]. AS №1549990 A1 SU. Sposob upravleniya processom predvaritel'noi mnogostupenchatoi distillyacii maslichnykh miscell / YA.M. Lesov i dr. MPK S11V 1/10. Zayavl. 21.08.87 №4299956/28-13. Opubl. 15.03.90. Byul. №10. - 4s.

[3]. AS №897840 SU. Sposob predvaritel'noi distillyacii maslyanykh miscell / V.T. Zolochevskii i dr. MPK S11V 1/10. Zayavl. 19.03.80 №2899329/28-13. Opubl. 15.01.82. Byul. №2. - 8s.

[4]. AS №806749 SU. Sposob distillyacii maslyanykh miscell / N.P. Ryabchenko i dr. MPK S11V 1/10. Zayavl. 07.06.78 №2647758/28-13. Opubl. 23.02.81. Byul. №7. - 6s.

[5]. AS №721473 SU. Sposob distillyacii maslyanykh miscell / YU.V. Ivanov i dr. MPK S11V 1/10. Zayavl. 16.08.77 №2519375/28-13. Opubl. 15.03.80. Byul. №10. - 3s. 
[6]. Ofitsiinyi sait firmy «HUM». URL: http://hum.com.tr/teknolojiler-ru_3/kstraktsiya/

[7]. Khobin V.A. Konspekt lektsii z kursu «Identyfikatsiia ta modeliuvannia tekhnolohichnykh ob `iektiv» dlia studentiv, yaki navchaiutsia za spetsialnistiu 151 «Avtomatyzatsiia ta komp iuterno-intehrovani tekhnolohii» dennoi ta zaochnoi formy navchannia.- Odesa: ONAKhT, 2016 - 96s.

[8]. Khobin V.A. Konspekt lektsii z kursu «Teoriia avtomatychnoho keruvannia» dlia studentiv, yaki navchaiutsia za spetsialnistiu 151«Avtomatyzatsiia ta komp iuterno-intehrovani tekhnolohii» dennoi ta zaochnoi formy navchannia.Odesa: ONAKhT, 2012.-Ch.1-112s.

[9]. Khobin V.A. Konspekt lektsii z kursu «Teoriia avtomatychnoho keruvannia» dlia studentiv, yaki navchaiutsia za spetsialnistiu 151 «Avtomatyzatsiia ta komp iuterno-intehrovani tekhnolohii» dennoi ta zaochnoi formy navchannia.Odesa: ONAKhT, 2019.-Ch.2-72s.

[10]. Khobin V.A. Sistemy garantiruyuschego upravleniya tekhnologicheskimi agregatami: osnovy teorii, praktika primeneniya. / Odesskaya nacional'naya akademiya pischevykh tekhnologii - Odessa: «TES», 2008. - 306 s.

УДК 004.896:621.798.1-033.5:66.013(477.74)

\title{
АВТОМАТИЗАЦІЯ БІЗНЕС-ПРОЦЕСУ ВИРОБНИЦТВА СКЛЯНОЇ ТАРИ
}

\author{
Аскаров Н. А. \\ Одеська національна академія харчових технологій \\ ORCID: https://orcid.org/0000-0003-2358-868X \\ E-mail: askarovnurlan777@gmail.com
}

Copyright (C 2021 by author and the journal “Automation of technological and business - processes”. This work is licensed under the Creative Commons Attribution International License (CC BY). http://creativecommons.org/licanses/by/4.0
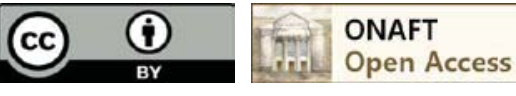

DOI:

Анотація. Для ефективної роботи підприємства необхідно високоефективне управління, яке в сучасних умовах спирається на певні програмні продукти. Питання розробки сучасних програмних продуктів є актуальним, багато розробників запропонували свої рішення.Загальним недоліком всіх рішень є низька гнучкість систем, - для їх адаптаціі під конкретне підприємство потрібна робота кваліфікованого програміста. На кафедрі автоматизації виробничих процесів та робототехнічних систем ОНАХТ в рамках дипломної роботи бакалавра було розроблено систему управління бізнес-прочесом виробництва скляної тари на підприємстві Ілона ЛТД. Створено модель організаційної структури підприємства, яка відображає розподіл роботи по підрозділах $і$ управлінським органам, між якими формуються певні відносини, пов'язані з реалізацією владних повноважень, потоків розпоряджень та інформації. Проведене виділення бізнес-процесів підприємства та створення його процесної моделі, яка описує процес послідовного перетворення матеріальних, сировинних і інформаційних потоків підприємства дозволило визначити процеси для подальшої їх автоматизації. Розроблена ВМРN нотація, яка відображує в зручной формі бізнес-процеси, які проходять в компанї, та їх зв'язок, послідовність, відношення до структурних підрозділів дозволила остаточно визначити конкретні прочеси для автоматизачії. Розроблене та затверджене технічне завдання на створення програмного забезпечення для АСУП, а саме створення програмного продукту зберігання, контролю, обліку $і$ аналізу даних про замовлення, складськи запаси сировини, готової продукціi, постачальників та замовників, результатів інвентарізаиї, розрахунків сировини для виробництва стало основою для розробки програмного продукту - сайту. Створення інтерфейсів та функиіоналу для кожного з керівників бізнес-процессів, яки були автоматизовані забезпечило зручне використання програмного продукту для користувача. Подальший розвиток питання автоматизаиії управління процесом виробництва скляної тари знайде в випускній роботі магістра.

Abstract. For effective operation of the enterprise it is necessary highly effective management, which in modern conditions relies on certain software products. The issue of developing modern software products is relevant, many developers have proposed their decisions. The general disadvantage of all decisions is low flexibility of systems, - for their adaptation, a qualified programmer is needed for their adaptation. At the Department of Automation of Production Processes and Robotic Systems of OANT in the framework of the bachelor's diploma work, a business process management system was developed at the production of a glass container at the Ilona Ltd. The model of the organizational structure of the enterprise is created, which reflects the distribution of work on subdivisions and management bodies, between which certain relations are formed 